\title{
Health effects of refractory ceramic fibres: scientific issues and policy considerations
}

\author{
L R Glass, R C Brown, J A Hoskins
}

\begin{abstract}
Objectives-To review the scientific literature on the health effects of refractory ceramic fibres (RCFs). The adverse effects of exposure to asbestos has led to concern about the potential for other fibrous materials to cause diseases. For this reason the human populations most heavily exposed to synthetic mineral fibres have been examined for any adverse effects and many types of fibre have been studied in animal experiments. One type of man made vitreous fibres (MMVFs), refractory ceramic fibres (RCFs), are principally used in thermal insulation at high temperatures-up to $1400^{\circ} \mathrm{C}$. As manufactured RCFs exist in a glassy, non-crystalline (sometimes called amorphous) state, they have various compositions, physical properties, and sized fibres.
\end{abstract}

Methods-All reports on the health effects of RCFs available up to the end of 1994 have been examined and the scientific literature reviewed although all publications have not necessarily been referenced.

Conclusions-In recent inhalation experiments conducted with both rats and hamsters at the Research and Consulting Company, Geneva, at the highest dose tested $\left(30 \mathrm{mg} / \mathrm{m}^{3}\right)$ there was an increased incidence of tumours in both species. Lower doses were only examined in the rat and at these doses there was no significant excess of lung tumours. Epidemiological investigations of workers engaged in the manufacture of ceramic fibres have shown a small excess of pleural plaques. This phenomenon is being further investigated but could be due to confounding exposures. The populations available for study are small and their exposures fairly short, but it is considered prudent that they should remain under surveillance for some time to come. This is despite the fact that present exposures in the ceramic fibre industry are low $(<1 \mathrm{f} / \mathrm{ml})$ and are being reduced.

(Occup Environ Med 1995;52:433-440)

Keywords: man made vitreous fibres; tumours; rodent inhalation; epidemiology

The health effects of exposure to amphibole asbestos are universally accepted although there is no clear consensus about chrysotile, a serpentine mineral and the commonest type of asbestos. It is prudent that other fibrous materials are examined for any effects similar to those caused by the natural materials and man made vitreous fibres continue to be studied. Most of the extensive experimental work and the epidemiological investigations of exposed workers have failed to detect any clear evidence of pathogenesis. In this paper the results of such research on one type of fibre-refractory ceramic fibre (RCF)-are reviewed. We think this is particularly timely as most of the data are not readily available and appear only in private reports or reports awaiting publication.

The pathogenicity of fibres is related to their size, morphology, and durability in tissue, ${ }^{1}$ and differences, especially in the durability in tissues, make it possible that different types of man made fibre pose substantially different levels of human risk. The terms used to describe different classes of fibres are often imprecise. The term ceramic fibre has been used for materials with very different physical properties and chemical compositions including crystals or whiskers of silicon nitride, silicon carbide, or potassium titanate and polycrystalline alumina or zirconia fibres. These crystalline fibres are not further discussed in this review. The RCFs that form the bulk of ceramic fibres are vitreous aluminosilicates manufactured as wools and are mostly used for high temperature insulation. They are high alumina silica glasses more closely related to other glasses than they are to crystalline materials from which they must be distinguished. Due to the random (spinning or blowing) processes used in manufacture of all the insulation wools (including RCFs) these contain fibres with diameters and lengths that vary both within individual products and between different product types.

History, applications, and properties of refractory ceramic fibres

The RCFs are made either by melting a combination of alumina and silica $\left(\mathrm{Al}_{2} \mathrm{O}_{3}\right.$ and $\mathrm{SiO}_{2}$ ) in roughly equal proportions, or by melting calcined kaolin. The melt is allowed to pass as a fine stream through a port in the bottom of the furnace where it is then acted on by a high velocity air jet or allowed to flow onto a series of spinning wheels. Other oxides such as zirconia $\left(\mathrm{ZrO}_{2}\right)$, boric oxide $\left(\mathrm{B}_{2} \mathrm{O}_{3}\right)$, or titania $\left(\mathrm{TiO}_{2}\right)$ are sometimes added to the melt to alter the temperature resistance or 
Table 1 Physical properties of refractory ceramic fibres

\begin{tabular}{lc}
\hline Property & Value \\
\hline Softening point $\left({ }^{\circ} \mathrm{C}\right)$ & $1740-1800$ \\
Refractive index & $1 \cdot 55-1 \cdot 57$ \\
Density $\left(\mathrm{g} / \mathrm{cm}^{3}\right)$ & $2 \cdot 6-2 \cdot 7$ \\
Elastic modulus (Gpa) & $80-100$ \\
Non-fibrous particulate & $40-60$ \\
shot (weight \%) & Variable, dependent upon \\
Diameter & manufacturing process \\
\hline
\end{tabular}

other properties of the resulting fibre. Table 1 shows the physical properties of some RCFs and table 2 shows the chemical formulation of three representative types.

Experimental RCFs were first produced in the early 1940 s and commercial production began in the 1950s. The energy crises of the 1970s stimulated their use as they were recognised as a cost effective and energy efficient substitute for hard brick refractories. Their use as high temperature insulation can reduce energy consumption by more than $50 \%$ compared with alternative products. ${ }^{2}$ The RCFs are used as insulation in furnaces and similar plant, at temperatures up to $1400^{\circ} \mathrm{C}$ and also have uses in "advanced composites" and for fire protection. Specialist uses for RCFs include the heat shields on aircraft (both commercial and military), tanks, and cruise missiles, and in the heat resistant tiles on the exterior of the space shuttle. Production of RCFs represents less than $2 \%$ of the overall MMVF market. As, unlike other MMVFs such as glass fibre and rockwool, they are rarely used in consumer products there is no possibility of significant exposure of the general public.

When RCF is exposed to temperatures in excess of $1000^{\circ} \mathrm{C}$, it can devitrify with the formation of mullite, a crystalline aluminium silicate, and silica, in the form of $\beta$-cristobalite. ${ }^{3}$ In a furnace this reaction occurs only at the hot inner surface of the lining and most of its thickness remains in the glassy state.

\section{Properties of fibres related to their effects on health}

It is now generally accepted that the effects of fibre exposure are related to three main variables-namely, dose, fibre length, and diameter and the persistence of fibres once deposited in the body.

Differences in persistence could determine the differences between the health effects of amphibole and chrysotile asbestos ${ }^{4}$ as chrysotile is cleared more rapidly from the lungs. Differences in durability between different man made fibres could mean that different fibres pose different levels of hazard.

Although the importance of durability is widely, but not universally, accepted there is much more agreement about the role of fibre dimension or morphology. The role of dimension is perhaps the "central dogma" of fibre toxicology with both length and diameter being important. As the least fibre diameter is the main determinant of respirability - that is, the capacity of a fibre to penetrate to the distal regions of the lung-it may also determine biological activity once deposited. The length of the fibres is also of importance as first shown by Gardner (quoted by Vorwald et al) in the 1930s in a series of inhalation experiments with mineral fibres where chrysotile consisting mainly of short fibres produced less asbestosis than longer chrysotile fibres. ${ }^{5}$

Injection or implantation of mineral fibres into the pleural or peritoneal cavities has elucidated the role of dimension particularly in determining the ability of a fibre to cause mesothelioma. ${ }^{6-11}$ The effect of fibre size has also been shown after inhalation exposure especially by Davis et al who used three samples of amosite asbestos with very different fibre lengths. ${ }^{1213}$ In a particularly dramatic demonstration of the role of length Wagner reported that shortening the fibres of erionite destroyed the extreme carcinogenicity of this zeolite mineral. ${ }^{14}$ Long fibres are also more active in various in vitro systems where clearance, deposition, and respirability cannot be playing a part. ${ }^{15}$ The role of fibre dimension as a determinant of activity in humans is more difficult to show but Lippmann has suggested that asbestosis, lung cancer, and mesothelioma are related to different sized fibres. ${ }^{16}$

Thus, long fibres are more biologically active and fibre diameter affects respirability, the final disposition of fibres in the body, and biological activity. The actual dimensions of fibres responsible for disease or the exact relation between activity and size remain uncertain.

Finally, exposure is rarely to fibres alonesome contamination with respirable nonfibrous particulates is inevitable even in experimental systems. Few experimental studies have considered the effects of such mixtures. In the case of humans, exposure is always to complex mixtures including, for example, tobacco smoke and in this case there is a well established synergistic interaction between asbestos and cigarette smoking. ${ }^{17}$

\section{Results of studies on RCFs} ANIMAL EXPERIMENTS

Ceramic fibres have been examined by injection or implantation by several authors, and the data is in agreement with the general finding that inocula of long thin fibres can cause tumours after injection into body cavities. ${ }^{781819}$ As a consequence of the lack of specificity of these methods most authors reject the production of tumours by 
placement into cavities as being predictive of human hazard. ${ }^{20-22}$ Only inhalation exposure simulates the normal route of exposure in humans and is the most relevant means for hazard identification and risk assessment of novel fibres. Unfortunately, inhalation bioassays are costly, complex, and time consuming although such studies are essential if the results of animal experiments are to produce results that are scientifically defensible. The first inhalation experiments with any fibres that produced clear positive carcinogenic effects were reported by Gross et al who had exposed rats to chrysotile asbestos. ${ }^{23}$ Gross et al had previously examined RCF in rats and determined that the effect was comparable with exposure to an inert dust. ${ }^{24}$ In a second RCF inhalation experiment Davis and coworkers exposed 48 Wistar rats to aerosols that contained 95 ceramic fibres $/ \mathrm{ml}$, in a whole body exposure for seven hours a day, five days a week for 12 months. ${ }^{25}$ Eight rats developed pulmonary tumours of which three were carcinomas. Unusually there was one peritoneal mesothelioma, a finding of unknown relevance.

The third experiment with ceramic fibres was carried out by Smith and coworkers who exposed both Osborne-Mendel rats and Syrian Golden hamsters to $200 \mathrm{f} / \mathrm{ml}$ for six hours a day, five days a week for two years. ${ }^{19}$ No excess of tumours was found in the rats and little, if any, fibrosis. In the hamsters there was no fibrosis but one animal developed a pleural mesothelioma.

The above investigations used only industrial ceramic fibres milled or ground to reduce overall fibre length. The aerosols produced contained material that was not respirable by rodents and fragments of the glassy ball "shot" that makes up about $50 \%$ by weight of these materials. In normal use this shot would not fragment and these contaminants would not make up part of any workplace RCF aerosol. The amount and size of the fibres in the lungs of the exposed animals was not reported. To compensate for the limitations of these earlier experiments a series of investigations were commissioned by the RCF industry and carried out at the Research and Consulting Company, Geneva. The RCF materials used in the Research and Consulting Company experiments were chosen to reflect the range of compositions to which humans might be exposed. These were: a kaolin based fibre; a "high purity fibre", made from alumina and silica; a zirconia fibre, containing $15 \%$ zirconia; and the kaolin fibre, heated to simulate a devitrified, "after use" fibre.

The RCF used in these experiments was isolated from the bulk material so as to remove the shot and maximise the content of fibres able to be respired by rodents. Size selection was carried out with a proprietary method that involved chopping the fibre, sieving, and grinding the shortened fibre, and two water elutriation size separation steps. Nearly 1 tonne of each commercial product had to be processed to provide the material used in the experiments. This material represented about $1 \%$, by mass, of the "as manufactured" product. The experimental fibre was "lofted" in a generator that did not further break the fibres and the animals were exposed in a nose only system in which the aerosol was not rebreathed. With these methods lung burden was maximised in relation to exposure ${ }^{26}$ and presumably this also maximised the potential for lung damage.

\section{Maximum tolerated dose studies}

As in any study of the carcinogenic potential of a substance, the intention of this investigation was to expose animals to the maximum dose that did not produce acute damage. Such a dose is difficult to determine in inhalation studies and the maximum tolerated dose was estimated after exposing Fischer 344 rats for one month to the zirconia fibre at three doses of 20,40 , and $60 \mathrm{mg} / \mathrm{m}^{3} .{ }^{27}$ Acute lung damage occurred at the two higher doses and $30 \mathrm{mg} / \mathrm{m}^{3}$ was then used as the maximum tolerated dose both for hamsters and rats with all four types of fibre. Both species were exposed to this dose (about $200 \mathrm{f} / \mathrm{ml}$ ), for six hours a day, five days a week, rats for 24 months and hamsters for 18 months. The animals were then held until survival of the exposed animals was reduced to $20 \%$. Hamsters were exposed to only the kaolin RCF whereas rats were exposed to all four types of fibre. Table 3

Table 3 Maximum tolerated dose study

\begin{tabular}{|c|c|c|c|c|c|c|c|c|c|}
\hline \multirow[b]{2}{*}{ Test species } & \multirow{2}{*}{$\begin{array}{l}\text { Animals } \\
\text { at risk } \\
\text { (n) }\end{array}$} & \multirow[b]{2}{*}{ Fibre type } & \multirow{2}{*}{$\begin{array}{l}\text { Aerosol } \\
\text { concentration } \\
(f / m l(S D)) \\
\left(m g / m^{3}(S D)\right)\end{array}$} & \multirow{2}{*}{$\begin{array}{l}\text { Concentration of } \\
\text { non-fibrous particles } \\
<3 \mu \text { diameter } \\
\text { (mean particles } / m l \text { ) }\end{array}$} & \multicolumn{2}{|c|}{$\begin{array}{l}\text { Aerosol fibre dimensions } \\
\text { geometric mean (GSD) }\end{array}$} & \multirow{2}{*}{$\begin{array}{l}\text { Fibrosis } \\
\text { (Wagner } \\
\text { grade) }\end{array}$} & \multicolumn{2}{|c|}{$\begin{array}{l}\text { Tumour incidence } \\
(\%)\end{array}$} \\
\hline & & & & & Diameter & Length & & Lung & Mesothelia \\
\hline \multirow{2}{*}{$\begin{array}{l}\text { Syrian } \\
\text { hamster }\end{array}$} & 119 & Air control & NA & NA & NA & NA & 1.0 & 0 & 0 \\
\hline & 112 & Kaolin & \multirow{2}{*}{$\begin{array}{l}256(58) \\
29 \cdot 2(7 \cdot 7) \\
\text { NA }\end{array}$} & 292 & $0.78(1.93)$ & $15 \cdot 9(2 \cdot 4)$ & $4 \cdot 0$ & 0 & 38 \\
\hline \multirow{5}{*}{$\begin{array}{l}\text { Rat } \\
\text { (Fischer } 344 / N \text { ) }\end{array}$} & 130 & Air control & & NA & NA & NA & $1 \cdot 0$ & 1.5 & 0 \\
\hline & 121 & Kaolin & \multirow{2}{*}{$\begin{array}{l}234(35) \\
29 \cdot 1(5 \cdot 2) \\
206(48) \\
30 \cdot 1(7 \cdot 8)\end{array}$} & 306 & $0.82(1.89)$ & $15.9(2.4)$ & $4 \cdot 0$ & $14 \cdot 0$ & $1 \cdot 7$ \\
\hline & 118 & $\begin{array}{l}\text { "After } \\
\text { service" } \\
\text { kaolin }\end{array}$ & & 210 & $1 \cdot 22(1 \cdot 68)$ & $9 \cdot 8(3 \cdot 8)$ & $3 \cdot 8$ & $4 \cdot 2$ & $0 \cdot 8$ \\
\hline & 121 & High purity & \multirow{2}{*}{$\begin{array}{l}213(44) \\
29 \cdot 2(7 \cdot 0) \\
268(45) \\
28 \cdot 9(4 \cdot 5)\end{array}$} & 401 & $0.85(1.91)$ & $17 \cdot 4(2 \cdot 4)$ & $4 \cdot 3$ & $14 \cdot 0$ & $1 \cdot 7$ \\
\hline & 121 & Zircona & & 333 & $0.88(1.92)$ & $12 \cdot 8(2 \cdot 5)$ & $4 \cdot 0$ & $8 \cdot 3$ & $2 \cdot 5$ \\
\hline
\end{tabular}

NA $=$ not applicable

The total number of lung tumours includes benign (adenoma) and malignant (adenocarcinoma) tumours and thus represent the worst case analysis, the number of animals at risk was defined as those animals exposed for 12 months. In the rat the lung tumour incidence is significantly different from the control group only at the maximum tolerated dose of the unheated fibres. 
Table 4 Multidose study of kaolin fibre in F344 rats

\begin{tabular}{|c|c|c|c|c|c|c|c|}
\hline \multirow{2}{*}{$\begin{array}{l}\text { Animals at } \\
\text { risk } \\
\text { (n) }\end{array}$} & \multirow{2}{*}{$\begin{array}{l}\text { Aerosol } \\
\text { concentration } \\
(\mathrm{f} / \mathrm{ml}(S D)) \\
\left(\mathrm{mg} / \mathrm{m}^{3}(S D)\right)\end{array}$} & \multirow{2}{*}{$\begin{array}{l}\text { Concentration of } \\
\text { non-fibrous particles } \\
<3 \mu \text { m diameter } \\
\text { (mean particles } / \mathrm{ml} \text { ) }\end{array}$} & \multicolumn{2}{|c|}{$\begin{array}{l}\text { Aerosol fibre dimensions } \\
\text { geometric mean (GSD) }\end{array}$} & \multirow{2}{*}{$\begin{array}{l}\text { Fibrosis } \\
\text { (Wagner } \\
\text { grade) }\end{array}$} & \multicolumn{2}{|c|}{$\begin{array}{l}\text { Tumour incidence } \\
(\%)\end{array}$} \\
\hline & & & Diameter & Length & & Lung & Mesothelial \\
\hline $\begin{array}{l}132 \\
126\end{array}$ & $\begin{array}{l}\text { NA } \\
162(37) \\
16 \cdot 5(1 \cdot 1)\end{array}$ & $\begin{array}{l}\text { NA } \\
156\end{array}$ & $\begin{array}{l}\text { NA } \\
0.82(1.99)\end{array}$ & $\begin{array}{l}\text { NA } \\
13 \cdot 8(2 \cdot 4)\end{array}$ & $\begin{array}{l}1 \\
4 \cdot 2\end{array}$ & $\begin{array}{l}0.8 \\
1 \cdot 6\end{array}$ & $\begin{array}{l}0 \\
0\end{array}$ \\
\hline 128 & $\begin{array}{l}91(34) \\
8.8(0.7)\end{array}$ & 141 & $0.80(2.03)$ & $13.9(2.5)$ & $4 \cdot 0$ & 3.9 & $0 \cdot 8$ \\
\hline 125 & $\begin{array}{l}36(17) \\
3.0(0.4)\end{array}$ & 51 & $0.80(2 \cdot 06)$ & $13 \cdot 5(2 \cdot 6)$ & $3 \cdot 2$ & $1 \cdot 6$ & 0 \\
\hline
\end{tabular}

Footnotes as for table 3.

summarises the properties of the aerosols used and the results.

A sample of chrysotile asbestos (the National Institute for Environmental and Health Studies (NIEHS) intermediate length sample) was included in the study; this was a short fibre with an arithmetic mean length of only $2.2 \mu \mathrm{m}$ (median $0.9 \mu \mathrm{m}$ ) and was used at $10 \mathrm{mg} / \mathrm{m}^{3}$. One rat in this group developed a mesothelioma. Hamsters had not previously been exposed to this sample of chrysotile.

Forty two of the hamsters exposed to the kaolin RCF were found to have mesothelial tumours after initial microscopic examination at postmortem examination and review of routine lung sections. These tumours were small and did not affect survival. Some interstitial and pleural fibrosis was also found. No mesothelial tumours were seen in the animals exposed to the chrysotile asbestos and no hamsters developed lung tumours. ${ }^{28-30}$

Rats exposed at $30 \mathrm{mg} / \mathrm{m}^{3}$ of the various chemically different RCFs developed a significant increase in lung tumours and a few mesotheliomas were also found in each RCF group, but these pleural tumour rates were not significant. The RCF exposure also caused lung and pleural fibrosis but less than was seen after exposure to chrysotile. All other lesions were consistent with expectations based on the types, strains, and ages of the animals in this study. ${ }^{29} 3132$

\section{Multidose study}

The study was extended by exposing three additional groups of rats to different concentrations of the kaolin RCF (3, 9, and 16 $\mathrm{mg} / \mathrm{m}^{3}$, corresponding to about 25,75 , and $115 \mathrm{f} / \mathrm{ml}$, table 4). Animals exposed to 16 $\mathrm{mg} / \mathrm{m}^{3}$ developed pleural and parenchymal fibrosis; at $9 \mathrm{mg} / \mathrm{m}^{3}$ there was mild parenchymal fibrosis, whereas at the lowest dose there were no irreversible effects. There was no excess of lung tumours at any of these doses; one rat in the $9 \mathrm{mg} / \mathrm{m}^{3}$ group developed a mesothelioma. ${ }^{29} 3334$ Table 4 shows the properties of the aerosols used and a summary of the results.

\section{Significance of the RCF experiments}

The results from the maximum tolerated dose studies indicate that exposure to extremely high concentrations of specially processed $\mathrm{RCF}$ can produce fibrosis and mesotheliomas in hamsters and fibrosis and lung tumours in rats. Lower doses of fibres were not tested in hamsters but these produced no excess lung tumours in rats. The sample of chrysotile had, in a previous inhalation experiment at the same exposure, caused lung tumours in about $20 \%$ of exposed rats ${ }^{28}$ and this compares with an incidence of rat lung tumours of $18.8 \%$ in the maximum tolerated dose study. The absence of mesotheliomas was predictable as this fibre is very much shorter than the RCFs and it was not expected to induce significant numbers of this tumour.

Hamsters do not readily develop lung tumours but are apparently sensitive to the pleural effects of the long (ceramic) fibres. It is regrettable that only the kaolin RCF has been examined at one dose in this species. Other long fibres should also be tested in this species as a means to understand the nature of the, so far, unique mesothelioma response. This is a new finding and suggests that hamsters might be useful in studies of this tumour. Most of the mesothelial lesions were microscopic, had no effect on life span, may not have been malignant, and probably would not have been detected in other studies with less sensitive detection protocols. The relevance and nature of these lesions are being further reviewed.

The data from the Research and Consulting Company studies of RCF have been used in a model of pulmonary deposition, retention, and clearance. ${ }^{35-37}$ This model suggests that exposures at the maximum tolerated dose may have been too high and that the lung burdens could have overwhelmed the clearance mechanisms of the lung. This overload condition has been found after extreme exposures to non-fibrous particulates and can induce lung tumours that seem to have no equivalent in exposed humans. ${ }^{38-40}$ Differences in deposition and clearance may also explain the differences between rats and hamsters and help in quantitative risk assessments of RCF. ${ }^{41-43}$

The histological appearance of the lungs and the existence of a no effect level in the rat is consistent with the possibility that the lung tumours at the maximum tolerated dose were produced by an epigenetic mechanism mediated by cytotoxicity followed by a consequent regenerative cell proliferation. ${ }^{28} 3134$

Despite the precautions used in preparing the fibres the aerosol used in the Research and Consulting Company studies contained nonfibrous, respirable particulate and this could have contributed to any reduction of clearance 
or affected the response to fibres by another mechanism. Davis and coworkers have reported that with asbestos and quartz mixtures incidence of mesothelioma was higher than that due to asbestos alone. ${ }^{44}$ It was suggested that exposure to a non-fibrous particulate can exacerbate the effects of fibres. Clearly the interaction between fibres and non-fibrous particles in the lungs of exposed animals requires much more investigation.

The Research and Consulting Company experiments have also provided information on the durability of RCFs, which had already been shown to be much less durable than asbestos both in vivo and in vitro. ${ }^{45} 46$ Such comparisons are complicated by other factors; for example Bellman et al reported that although all the man made fibres, including RCFs, were cleared from the lung the numbers of chrysotile fibres increased due to longitudinal splitting. These authors also reported that ceramic fibres were less soluble than other MMVFs. In the Research and Consulting Company experiments the overall clearance of those ceramic and glass fibres longer than $5 \mu \mathrm{m}$ occurred at similar rates. In support of the rapid clearance of RCFs preliminary evidence indicates that RCFs in human lungs are altered in both chemistry and structure ${ }^{48}$ Any hazard posed by human exposure to RCF would be dramatically reduced if the fibres are dissolving and being weakened and then experiencing a comminution by fragmentation although this might not occur rapidly enough to reduce the hazard to rodents.

Extrapolations between results in animal experiments and human risk are confounded by the issue of fibre durability. Fibre dissolution is a physical phenomenon, presumably occurring at the same speed in man and animals whereas biological responses are likely to relate to lifespan. Thus, even for the same exposure laboratory animals are more likely to show adverse responses than humans. In animals fibres can persist at the point of deposition for a period that is a substantial part of the life span causing a sustained insult that could result in a compensatory hyperplasia. Such fibres might not persist for a large enough fraction of a human's life, to cause this type of chronic wounding.

At worst the rate at which material may be given to an animal can be such as to overwhelm the clearance and dissolution processes. Consequently the results of animal experiments might overestimate the possibility of any effect of exposure to fibres at workplace concentrations in humans. These considerations are additional to the more general criticisms of animal carcinogenicity bioassays that involve extremely high doses. ${ }^{49} 50$

\section{INVESTIGATIONS ON HUMAN POPULATIONS} EXPOSED TO RCFS

These investigations have concentrated on workers in the manufacturing plants as they are probably the cohort with the heaviest exposure. Many of the plants involved have also manufactured hard refractories and may have used asbestos and so care must be taken in the attribution of any effect to RCFs alone.

European Ceramic Fibre Insulation Association (ECFIA) ceramic fibre morbidity study

(1986-1989)

This investigation of the health of over 650 employees in the manufacture of RCF did not identify any evidence of lung disease in those who had never smoked. Lung function tests of current and ex-smokers showed effects on small airways that were consistent with their smoking habit. The possibility of a relation between duration of exposure to RCF and decreased lung function was also raised, but judged to be of no clinical significance. Symptoms of dry cough and breathlessness were also found but could not be attributed to RCF exposure. ${ }^{51}$ A second European study is to be undertaken in the near future.

\section{Preliminary United States radiographic study (1986)}

Examination of chest $x$ ray films of 214 current employees who worked in two RCF manufacturing plants showed no effects attributable to RCF exposure. The findings from the $x$ ray films were reported to be consistent with those found in similar surveys of other factory workers not exposed to fibres. ${ }^{52}$

American industry studies (1987-present)

Lockey and coworkers conducted a longitudinal pulmonary morbidity study of United States workers in the manufacture of RCF or RCF products. This cohort $(n=742)$ represents $98.5 \%$ of the exposed population. Exposure was classified only as either RCF exposed (production workers) or unexposed (non-production workers). In the exposed group the only measures of exposure were duration and time since first employment in production. Thirty per cent of the cohort had between 10 and 20 years of exposure and $4 \%$ more than 20 years.

There was a decrease of between $2 \%$ and $3 \%$ in forced vital capacity and forced expiratory volume in one second. These effects were correlated with smoking history and with the duration of exposure. These changes were not clinically significant and similar decrements have been found in manual workers with exposure to other dusty environments. ${ }^{5354}$

Pleural plaques were identified by at least two of three qualified $B$ reader radiologists in posterioanterior $x$ ray films of $2 \cdot 4 \%$ of the production employees. There was no evidence of interstitial fibrosis and no excess of lung cancer; no mesotheliomas were reported. ${ }^{53}$ 55-58

In a more detailed study of current and former employees at two of the plants, a complete medical history was taken and bilateral oblique angle $x$ ray films of the chest were also taken. Permission was sought from employees who required thoracic surgery and at postmortem examination for any tissue taken to be examined for the presence of fibres and disease. 
As in the wider survey, there was an increase in the prevalence of respiratory symptoms in current and former production workers compared with non-production workers. Although the symptoms seemed to correlate with increased duration of employment in production, the prevalence of the symptoms was similar to that found in other people who have worked in other dusty environments and thus were not specific for exposure to ceramic fibres.

Spirometric findings were again dependent on the smoking habits of the employee. In contrast with non-smokers, smokers had an additional job related small reduction in some measures of respiratory function. This decrement in lung function was associated with duration of employment in a production job, cumulative exposure to $\mathrm{RCF}$, and smoking history. Again these effects did not reach clinical significance. This population is continuing to be monitored to ascertain if the decline in lung function continues and if there is any sensitive subgroup.

Pleural plaques were found in $0.9 \%$ of nonproduction workers $(2 / 214)$ and production workers with less than 10 years of RCF exposure $(1 / 117)$, in $2 \cdot 8 \%$ of workers with 10 to 20 years exposure (7/248), and in $12.5 \%$ of workers with more than 20 years of exposure (9/72). These crude incidence figures clearly require correction for age. Minimal or no changes were found in lung parenchymal tissue. Of the 652 workers for whom chest $x$ ray films were available three $(0.46 \%)$ had borderline parenchymal changes a prevalence similar to that found in other working populations.

A case-control study is being carried out in this group in an attempt to ascertain if the incidence of pleural plaques can be attributed to previous exposure to asbestos. Cases and controls have been interviewed with a specially structured questionnaire designed to provide information on all exposures to asbestos. At present there remains some relation between exposure to RCF and the development of pleural plaques that must be investigated further.

The number and causes of deaths in the cohort was consistent with that in the general population. In particular no excess risk of lung cancer was found (3.5 expected; 4 observed). Again there were no mesotheliomas. ${ }^{59}$

These studies are being extended for another five years.

Relevance of the epidemiological investigations Over $80 \%$ of the workers exposed during the manufacture of RCF in both Europe and the United States have been included in these studies. These investigations have maximised the likelihood of identifying any adverse effect although the size of the study population is less, and exposures shorter, than that of other cohorts with occupational exposure to dusts or fibres. It would be difficult to increase the size of the cohort and it presumably represents workers with the greatest exposure to
RCF. The aggregated evidence from all these studies does not show an adverse health effect from exposure to RCF but does warrant extension of the surveys. To date the main finding is the presence of pleural plaques in a few former and current workers. It is generally held that pleural plaques are benign and, particularly in the absence of asbestosis, are most appropriately recognised as indicators of exposure to asbestos. ${ }^{60}$

\section{Current exposures to $R C F$}

Preliminary estimates indicate that there are no more than 33000 people in the United States and 25000 in Europe who could be exposed to these materials. These occupational exposures can be limited and are amenable to a high level of control, indeed both engineering controls and improved work practices are being implemented. ${ }^{61}$ There are few consumer applications, and those there are usually involve fibre that is enclosed or encapsulated so that any potential for exposure of the general public is minimal.

In the industry a lack of exposure data, changes in the methods of exposure assessment, and poor record retention make it extremely difficult to reconstruct historical exposures; however, these were certainly higher than those of today, which are mostly below $1 \mathrm{f} / \mathrm{ml}^{62}{ }^{63}$ Thus the concentrations that produced lung tumours in the Research Consulting Company animal studies were over 200 times higher than the typical industrial human exposures. Further, measurement of the bivariate size distribution of fibres from selected occupational settings, ${ }^{63}$ suggests that the animals were exposed to a much higher concentration of the thin long fibres thought to be responsible for the production of disease.

\section{Discussion and conclusions}

Any estimate of the degree of hazard posed by a substance requires knowledge of that substance, the environment in which exposure can occur, the exposed population, and the duration and frequency of the exposure. To understand these issues for RCF their manufacturers have undertaken the design and completion of the health studies already discussed as part of a formal product stewardship programme.

Adverse effects can be produced in rodents exposed to high concentrations of an RCF particulate aerosol, although the relevance of this to human hazard requires further analysis. This must take account of the facts that fibre dissolution occurs in calendar time although the production of disease occurs in physiological time; ceramic fibre is far less durable in the lung than chrysotile, the least durable asbestos mineral. ${ }^{46} 47$ The natural minerals can also split longitudinally producing more fibres, although vitreous fibres including RCFs do not.

All the biases intrinsic in animal studies mean that hazard is likely to be overestimated rather than underestimated and the occurrence of tumours in animals induced only by 
very high doses may have little relevance to humans. It also seems likely that at the highest exposures the animals' lungs were overloaded-a condition that can result in lung tumours in rodents whatever type of particle is inhaled. ${ }^{38}$ The mesotheliomas found in hamsters in the Research and Consulting Company study were microscopic and not life threatening and their exact histopathology is currently being reviewed. Any comparison with mesotheliomas in humans and these small compact lesions, especially their use in quantitative risk assessment, requires investigation. There is certainly a case for supporting the common assertion that further work needs to be done.

Epidemiological investigations have included morbidity and mortality studies in cohorts from manufacturing establishments that are assumed to represent the most heavily exposed population. To date there is no evidence that exposure to RCF can cause any respiratory disease. As no workers have been exposed over a full working life it may be some time before definitive human studies can be undertaken.

Despite these uncertainties there are continuing efforts to control exposure to RCFs and so reduce any risk. ${ }^{261626465}$ It is probable that current exposures are so low and are still being reduced that human disease will not develop and so the human relevance of the animal results will never become clear. It is certainly true that extrapolation from such experiments that used extreme doses of a highly refined fibre fraction isolated from more complex bulk materials will never be simple.

Finally, it must be emphasised that the objective of these studies and control measures is to capture the undoubted benefits of RCFs to industry and the environment while controlling any risks at all stages of manufacture, use, and disposal.

1 International Agency for Research on Cancer. Man-made mineral fibres and radon. LARC Monogr Eval Carcinog Risks Hum 1988;43.

2 Everest Consulting Associates. Cost impacts of a potential ban on refractory ceramic fibre for furnace related applications; technical and economic analysis. Submitted to the United States Environmental Protection Agency (USEPA), Washington DC: Refractory Ceramic Fibre Coalition (RCFC), 1992

3 Brown RC, Hoskins JA, Sara EA, Evans CE, Young J, Laskowski JJ, et al. The effects of heating and devitrification on the structure and biological activity of aluminosilicate refractory ceramic fibres. Ann Occup $H y g$ 1992;36:115-29.

4 Mossman BT, Bignon J, Corn M, Seaton A, Gee JBL. Asbestos: scientific developments and implications for public policy. Science 1990;247:247-301.

5 Vorwald AJ, Durkan TM, Pratt PC. Experimental studies of asbestosis. American Medical Association Archives of Industrial Hygiene and Occupational Medicine 1951;3: Industrial $1-43$.

6 Pott F. Some aspects of the dosimetry of the carcinogenic potency of asbestos and other fibrous dusts. StaubReinholt Lufi 1978;38:486-90.

7 Pott F, Roller M, Ziem U, Reiffer F-J, Bellmann B, Rosenbruch M, Huth F. Carcinogenicity studies on natural and man-made fibres with the intraperitoneal test in rats. In: Bignon J, Peto J, Saracci R, eds. Non-occupational exposure to mineral fibres. Lyon: International Agency for Research on Cancer, 1989;173-9. (IARC Sci Publ No 90.)

8 Pott F, Roller M, Rippe RM, Germann P-G, Bellman B. Tumours by the intraperitoneal and intrapleural routes and their significance for the classification of mineral fibres. In: Brown RC, Hoskins JA, Johnson NF, eds. Mechanisms in fibre carcinogenesis. Nato Asi series $A$ life sciences. Vol 223. New York: Plenum Press, 1991:547-65.

9 Stanton MF, Layard M, Tegeris A, Miller E, Kent E. Carcinogenicity of fibrous glass: pleural response in the rat in relation to fibre dimension. $\mathcal{F}$ Nat Cancer Inst 1977;58:587-603.

10 Stanton MF, Layard M, Tegeris A, Miller E, May M, Morgan E, Smith A. Relation of particle dimension to carcinogenicity in amphibole asbestos and other fibrous materials. $\mathscr{F}$ Natl Cancer Inst 1981;67:965-75.

11 Stanton MF, Wrench C. Mechanisms of mesothelioma induction with asbestos and fibrous glass. $\mathcal{F}$ Nat Cancer induction with asbesto
Inst 1972;48:797-821.

12 Davis JMG, Addison J, Bolton RE, Donaldson K, Jones $A D$, Smith $T$. The pathogenicity of long versus short fibre samples of amosite asbestos administered to rats by inhalation and intraperitoneal injection. British fournal of Experimental Pathology 1986;67:415-30.

13 Davis JMG, Jones AD. Comparisons of the pathogenicity of long and short fibres of chrysotile asbestos in rats. British fournal of Experimental Pathology 1988;69: 717-37.

14 Wagner JC. Biological effects of short fibres. In: Proceedings of the VIIth International Pneumoconiosis Conference. Cincinnati: US Department of Health and Human Services, 1990. (DHSS (NIOSH) Publ No 90-108, part II.)

15 Petruska JM, Mossman BT, Brown RC, Hoskins JA Mechanism of action of mineral fibres as studied by in Mechanism of action of mineral fibres as studied by in
vitro methods. In: Liddell D, Miller K, eds. Mineral fibres vitro methods. In: Liddell D, Miller K, eds. Mineral fibrth. Boca Raton: CRC Press, 1991:303-19.

16 Lippman M. Asbestos exposure indices. Environ Res 1988;46:86-106.

17 Saracci R. Asbestos and lung cancer: an analysis of the epidemiological evidence on the asbestos-smoking interaction. Int $\mathcal{F}$ Cancer 1977;20:323-31.

18 Wagner JC, Berry G, Timbrell V. Mesotheliomas in rats after inoculation with asbestos and other materials. $\operatorname{Br} \mathcal{F}$ Cancer 1973;28:173-85.

19 Smith DM, Ortiz LW, Archuleta RF, Johnson NF. Longterm health effects in hamsters and rats exposed chronically to man-made vitreous fibers. Ann Occup Hyg cally to man-made

20 World Health Organisation. Validity of methods for assessing the carcinogenicity of man-made fibres. Lyon: executive summary of a WHO consultation, 1992

21 Hesterberg TW, Vu V, Chase GR. Use of animal models to study man-made fibre carcinogenesis. In: Brinkly B, Lechner J, Harris C, eds. Cellular and molecular aspects of fibre carcinogenesis. Cold Spring Harbor, NY: Cold Spring Harbor Laboratory, 1991:183-205.

22 McClellan RO, Miller FJ, Hesterberg TW, Warheit DB, Bunn WB, Kane A, et al. Approaches to evaluating the toxicity and carcinogenicity of man-made fibres: sum-
mary of a workshop held November 11-13, 1991, Durham, North Carolina. Reg Toxicol Pharmacol 1991; 16:321-64.

23 Gross P, De Treville RTP, Tolker EB, Kaschak M, Babyak MA. Experimental asbestosis: the development of lung cancer in rats with pulmonary deposits of chrysotile asbestos dust. Arch Environ Health 1967;15: 343-55

24 Gross P, Westrick ML, Shrenk HH, McNerney JM. The effect of synthetic ceramic fibre dust upon the lungs of rats. American Medical Association Archives of Industrial Health 1956;13:161-6.

25 Davis JMG, Addison J, Bolton RE, Donaldson K, Jones $\mathrm{AD}$, Wright $\mathrm{A}$. The pathogenic effects of fibrous ceramic material aluminium silicate glass administered to rats by inhalation and peritoneal injection. In: Biological effects of man-made mineral fibres. Proceedings of a WHOILARC Conference, Copenhagen, April 20 to 22, 1982. Vol 2. Conference, Copenhagen, April 20 to
Geneva: WHO/IARC 1984,303-11.

26 Bernstein DM, Drew R, Kuschner M. Experimental approaches for exposure to sized glass fibers. Environ Health Perspect 1980;34:47-57.

27 Glass LR, Mast RW, Chevalier J, Hesterberg TH, Anderson R, McConnell EE, Bernstein DM. Sub acute (28 day) nose only inhalation study of size selected refractory ceramic fibre (RCF) in male fischer 344 rats. The Toxicologist 1993;13:34.

28 McConnell EE, Mast RW, Hesterberg TW, Chevalier J, Kotin P, Bernstein DM, et al. Chronic inhalation toxicity of a kaolin based refractory ceramic fibre (RCF) in syrian golden hamsters. Inhalation Toxicology 1995 (in press).

29 Bunn WB, Bender JR, Hesterberg TW, Chase GR, Konzen JL. Recent studies of man-made vitreous fibres, chronic animal inhalation studies. $\mathcal{F}$ Occup Med 1993; chronic animal

30 Mast RW, McConnell EE, Glass LR, Hesterberg TW, Anderson R, Bernstein DM. Inhalation oncogenicity of kaolin refractory ceramic fibre (RCF) in hamsters-final results. The Toxicologist 1992;12:377.

31 Mast RW, McConnell EE, Anderson R, Chevalier J, Kotin $\mathrm{P}$, Berstein DM, et al. Studies of the chronic toxicity (inhalation) of four types of refractory ceramic fibre in male fischer 344 rats. Inhalation Toxicology 1995 (in press).

32 Glass LR, Mast RW, Hesterberg TH, Anderson R McConnell EE, Bernstein DM. Inhalation oncogenicity of refractory ceramic fibre (RCF) in rats-final results The Toxicologist 1992;12:377. 
33 Mast RW, McConnell EE, Glass LR, Hesterberg TW, Thevenaz P, Chevalier J, Anderson R. A multiple dose chronic inhalation toxicity study of kaolin refractory chronic inhalation toxicity study of kaolin refractory ceramic fibre $(\mathrm{RCF})$.

34 Mast RW, McConnell EE, Hesterberg TW, Chevalier J, Kotin P, Thevenaz P, et al. A multiple dose chronic inhalation toxicity of size selected kaolin refractory ceramic fibre (RCF) in male fischer 344 rats. Inhalation Toxicology 1995 (in press)

35 Yu CP, Asgharian B, Abraham JL. Mathematical modelling of alveolar clearance of chrysotile asbestos fibers from the rat lungs. Fournal of Aerosol Science 1990;21: 587-94.

36 Yu CP, Asgharian B. A kinetic model of alveolar clearance of amosite asbestos fibers from the rat lung at high lung burdens. Fournal of Aerosol Science 1990;21:21-7.

37 Yu CP, Asgharian B, Pinkerton KE. Intrapulmonary deposition and retention modelling of chrysotile fibers in rats. fournal of Aerosol Science 1991;22:757-63.

38 Hext PM. Current perspectives on particulate induced pulmonary tumours. Hum Exp Toxicol 1994;13:700-14.

39 Morrow PE. Dust overloading of the lungs: update and appraisal. Toxicol Appl Pharmacol 1992;113:1-12.

40 Lewis TR, Morrow PE, McClellan RO, Raabe OG Kennedy GR, Schwartz BA, et al. Establishing aerosol exposure concentrations for inhalation toxicity studies. Toxicol Appl Pharmacol 1989;99:377-89.

41 Yu CP, Zhang L, Oberdoerster G, Mast RW, Glass LR, Utell MJ. Deposition modelling of refractory ceramic fibres in the rat lung. Fournal of Aerosol Science 1995 (in press).

42 Yu CP, Zhang L, Oberdoerster G, Mast RW, Glass LR Utell MJ. Clearance of refractory ceramic fibres (RCF) from the rat lung: development of a model. Environ Res 1995 (in press)

43 Yu CP, Ding J, Zhang L, Oberdoerster G, Mast RW, Glass LR, Utell MJ. Deposition and clearance modellin of inhaled kaolin refractory ceramic fibres (RCF) in hamsters-comparison with rat results. fournal of Aerospace Science 1995 (in press)

44 Davis JMG, Jones AD, Miller BG. Experimental studies in rats on the effects of asbestos inhalation coupled with the inhalation of titanium dioxide or quartz. Int $₹$ Exp Pathol 1991;72:501-25.

45 Scholze $\mathrm{H}$, Conradt $\mathrm{R}$. An in vitro study of the chemical durability of siliceous fibres. Ann Occup Hyg 1987;31: 683-92.

46 Hammad Y, Simmons W, Abdel-Kader C, Reynolds C, Wiell $H$. Effect of chemical composition on pulmonary clearance of man-made mineral fibres. Ann Occup Hyg

47 Bellman B, Muhle H, Pott F, Konig H, Kloppel $H$, Spurny K. Persistance of man-made mineral fibres (MMMF) and asbestos in rat lungs. Ann Occup Hyg
1987;31:693-709.

48 Sebastien P, Vergnon JM, Blanchard O, Wastiaux A Emonot KL. Durability of ceramic fibres in the human lung: preliminary results. Presented At The 23rd International Congress on Occupational Health, September 1990. Stockholm: 1990 .

49 Ames B, Gold LS. Too many rodent carcinogens: mitogenesis increases mutagenesis. Science 1990;249:970. 50 Cohen SM, Ellwein LB. Cell proliferation in carcinogenesis.
Science 1990;249:1007-11.
51 Trethowan WN, Burge PS, Harrington JM, Calvert I, Rossiter C. Study of the respiratory health of employee in seven European plants that manufacture ceramic fibres. Occup Environ Med 1995;52:97-104.

52 Horvath EP. Report to Standard Oil. Chest $x$ ray results from current New Carlisle and Niagara Falls area employees. 1986

53 Lockey J, Lemasters G, Rice C. An industry wide pulmonary morbidity study of workers manufacturing refractory ceramic fibres and RCF products. Presented at the 33 . Int ceramic Congress on Occupational Health, September, 1990 Stockholm: 1990

54 Lockey J, Lemasters G, Rice C, McKay RT, Gartside PS. A cross sectional analysis of respiratory health among current refractory ceramic fibre employees. Submitted to the Thermal Insulation Manufacturers Association (TIMA). Washington, DC: 1991

55 Lemasters G, Lockey J, Rice C, et al. Radiographic changes among workers manufacturing refractory ceramic fibre and products. Ann Occup Hyg 1994;18(suppl 1):745-51.

56 Lockey J. Issues associated with occupational exposure to refractory ceramic fibres. Presented to the spring meeting of the American College of Occupational and Environmental Medicine, May, 1992. Cincinnati: 1992.

57 Lockey J, Lemasters G, Rice C. An industry wide pulmonary morbidity study of current and former workers manufacturing refractory ceramic fibres and products. Presented at the refractory ceramic fibres and products. Presented at the
BOHS 7th International Symposium on Inhaled Particles,
Edinburgh, September, 1991.

58 Lockey L, Lemasters G, Rice C. Pleural plaques-a marker of exposure to refractory ceramic fibres. Presented at the Society of Epidemiologic Research, fuly, 1992. Cincinnati: 1992

59 Lockey J, Lemasters G, Rice C, McKay RT, Gartside PS. A retrospective morbidity, mortality and nested case-control study of the respiratory health of individuals manufacturing refractory ceramic fiber and $R C F$ products. Submitted to the Refractory Ceramic Fiber Coalition (RCFC) Washington, DC: 1993.

60 Weiss W. Asbestosis related pleural plaques and lung cancer. Chest 1993;103:1854-9.

61 Barrows GL, Chen SH, Shemanski L. The refractory ceramic fibre coalition's product stewardship program. American Ceramic Society Bulletin 1993;72:28-34.

62 Everest Consulting Associates. Report to the Occupational Safety and Health Administration (OSHA). An analysis of the economic feasibility of a $1 \mathrm{flml}$ permissible exposure limit (PEL) for the refractory ceramic fibre industry. Washington, DC: Sponsored by the Refractory Ceramic Fibre Coalition (RCFC), 1992.

63 Hori H, Toshiaki H, Fujino A, Yamato H, Ishimatsu S, Oyabu T, Tanaka I. Measurement of airbome fibres in manufacturing and processing factories. $A n n$ Occup Hyg 1993;37:623-9.

64 Everest Consulting Associates. Waste generation and management in the manufacture, processing and use of refractory ceramic fiber (RCF). Washington, DC: Sponsored by the ceramic fiber (RCF). Washington, DC: Sponsored by
Refractory Ceramic Fibre Coalition (RCFC), 1994.

65 Breitsman WJ, Maxim LD, Allshouse J, Crankshaw O Wrenn C. Refractory ceramic fibre emissions from domestic production facilities and related matters: phase I final report. Prepared on behalf of TIMA, Inc for the Office of Toxic Substances (OTS), Office of Pesticides and Toxic Substances, US Environmental Protection Agency (EPA). 